\title{
Evaluation of Shore A hardness of maxillofacial silicones: the effect of dark storage and nanoparticles
}

\section{Purpose}

Little has been reported how the addition of nanoparticles could affect the hardness of maxillofacial silicones. The purpose of this study was to evaluate the effects of different types of nanoparticle additives and dark storage for 2-years on the Shore A hardness of two types of maxillofacial silicone elastomers.

\section{Materials and Methods}

A-2000 and A-2006 Room Temperature Vulcanized (RTV) silicone elastomers were tested in this study. Silaned silica, fumed silica and titanium dioxide nanoparticles at concentrations of $10 \%$ by volume were used as fillers for the maxillofacial silicone elastomers. A total of 64 silicone specimens were fabricated, which includes 8 samples, $30 \times 10 \mathrm{~mm}$ in size, from each silicone elastomers for each subgroup and also controls. After the initial Shore A hardness measurements, specimens were kept in dark conditions at room temperature for 2 years. The final measurements were then taken from the silicone specimens. All data were statistically analyzed.

\section{Results}

For both types of silicones, there was statistically significant differences among study groups $(p<0.001)$. Fumed silica group showed the lowest hardness values in A-2000 after storage. However, no significant difference was observed between control and fumed silica groups. Control group showed the lowest hardness values in A-2006, while the highest hardness values were found in fumed silica group; there was no significant difference between silica and silane groups.

\section{Conclusion}

Shore A values of the specimens were within the acceptable range for the maxillofacial silicones after aging. Nanoparticle addition did not prevent hardening of the silicone elastomers with time.

Keywords: Aging; hardness; nanoparticles; silicone elastomers; Shore A

\section{Introduction}

Maxillofacial prostheses are still being used to treat congenital and acquired defects of the head and neck region, despite advances in plastic surgery $(1,2)$. Maxillofacial prostheses provide a practical alternative by giving patients a normal appearance, esthetics, and social acceptance (3, 4). Currently, several types of materials can be used in maxillofacial prosthodontics such as chlorinated polyethylene, polymethylmethacrylates, polyurethanes, latex, and silicone elastomers. Silicone elastomers are widely used because of their favorable properties, including acceptable tear and tensile strengths, chemical inertness, high elongation percentage, ease of manipulation and biocompatibility $(5,6)$. Despite their wide use, they also suffer from deterioration of color and loss of physical, mechanical as well as dynamic properties in clinical practice. The average service life of a maxillofacial prosthesis ranges therefore from 6 to 18 months (6).

\author{
Pınar Çevik
}

ORCID ID of the author: P.Ç. 0000-0003-1970-7543 Department of Prosthodontics, Gazi University Faculty of Dentistry, Ankara, Turkey

Corresponding Author: Pınar Çevik E-mail: dt_pinarcevik@yahoo.com

Received: 22 May 2017 Revised: 17 July 2017 Accepted: 25 July 2017

DOI: $10.26650 /$ eor.2018.469 
Limited research has been conducted to enhance the mechanical and physical properties of maxillofacial silicones by adding nanoparticles $(1,7)$. Nanoparticles could diffuse the silicone matrix, which leads to the formation of the three-dimensional network within the silicone chain $(3,7)$.

Surface hardness can be described as the resistance of the material against vertical perforation (8). The hardness of the maxillofacial silicone elastomer is determined by the density of cross-links and the surface characteristics of polymer network (9). An ideal maxillofacial silicone elastomer should have an optimum hardness value to mimic the surrounding tissues (10).

Previous studies have evaluated the effect of artificial aging and real time aging on the mechanical and physical properties of different types of maxillofacial silicones. However, no previous study evaluated the effect of long-term dark storage on the hardness of nanoparticle added two types of room temperature vulcanized (RTV) maxillofacial silicone elastomers. Therefore, the purpose of this study was to evaluate the effect of long-term dark storage on the hardness of nanoparticle added two types of RTV maxillofacial silicone elastomers. The null hypotheses tested in this study were twofold; first, the natural aging would not affect the hardness of nanoparticle added maxillofacial silicone elastomers and second, Shore A hardness of the nanoparticle added specimens would be reduced after dark storage.

\section{Materials and methods}

\section{Specimen preparation}

The materials used in this study are given in Table 1. Platinum based A-2000 and A-2006 RTV type silicone elastomers were tested. A total of 64 silicone elastomer specimens $(\mathrm{N}=64)$ were fabricated from $\mathrm{A}-2000$ and $\mathrm{A}-2006$ silicones. Silane treated silica, fumed silica and titanium dioxide $\left(\mathrm{TiO}_{2}\right)$ nanoparticles were used as fillers. A metal mold was fabricated in accordance with the American Society for Testing and Materials (ASTM) D2240-68 standard for the standardization of the silicone specimens for the hardness tests.

For the fabrication of specimens in control group (Group $1)$, the homogenous silicone mixtures were prepared from A-2000 and A-2006 silicone elastomers, respectively. The ratio of the silicone elastomers were 1:1 for part $A$ and part $B$ of the silicones. A thixotropic agent, which prevents air bubble formation, was added to the silicone mixture and mixed by hand, according to the manufacturer's instructions. Thus, Group 1 with no addition of nanoparticles served as the control group for A-2000 and A-2006 silicone elastomers. For Group 2, 12 $\mathrm{nm}$ hydrophilic fumed silica nano particles were added at $10 \%$ concentration by volume to the silicone mixture. For Group 3, $12 \mathrm{~nm}$ silane-treated hydrophobic silica nanoparticles were incorporated to the silicone mixture at $10 \%$ concentration by volume. For Group 4, $30 \mathrm{~nm} \mathrm{TiO}_{2}$ nanoparticles were added to the silicone mixture at $10 \%$ concentration by volume. The final silicone mixture was poured to the metal mold and silicone specimens were polymerized. The manufacturer recommends the polymerization to take place at $75^{\circ} \mathrm{C}$ for 3 or 4 hours in stone molds and dry oven. They also recommend higher polymerization degree and lesser time if the metal molds used. For standardization of the specimens, metal molds, instead of stone molds, and constant pressure with proper degree of temperature were selected. Therefore, the polymerization process was set for the specimens as 6 minutes in $60^{\circ} \mathrm{C}$ under a hydraulic press (HD80; Motor Operated, Hidroliksan, Konya, Türkiye) in metal molds, according to the method described in a previous study (1). Eight silicone specimens were fabricated for each study group $(n=8)$. Thus, a total of 64 silicone specimens from A-2000 and A-2006 silicone elastomers (32 in each) were used in this study for the hardness tests.

\section{Shore A hardness measurements}

Silicone specimens in $30 \mathrm{~mm}$ diameter and $10 \mathrm{~mm}$ thickness were prepared in a metal mold in compliance with the ASTM D2240-68 standard (Figure 1). The hardness measurements of the specimens were made by using a digital Shore A durometer (Shore Leverloader, Duratronic, Akron, OH, USA). Three hardness measurements were taken from each specimen as Shore units and the average values were calculated as the final Shore A value, before and after the dark storage of the specimens.

\section{Storage conditions}

Dark storage performed for the silicon specimens included storing the specimens in room temperature $23^{\circ} \mathrm{C} \pm 2^{\circ} \mathrm{C}$ and relative humidity in pigment free plastic bags. Specimens then placed in a lightproof wood box for 2-years. At the end of this period, specimens were removed and tested by using the digital Shore A durometer (Figure 2).

\section{Statistical analysis}

The collected data from all groups were imported to Statistical Package for the Social Sciences software version 20

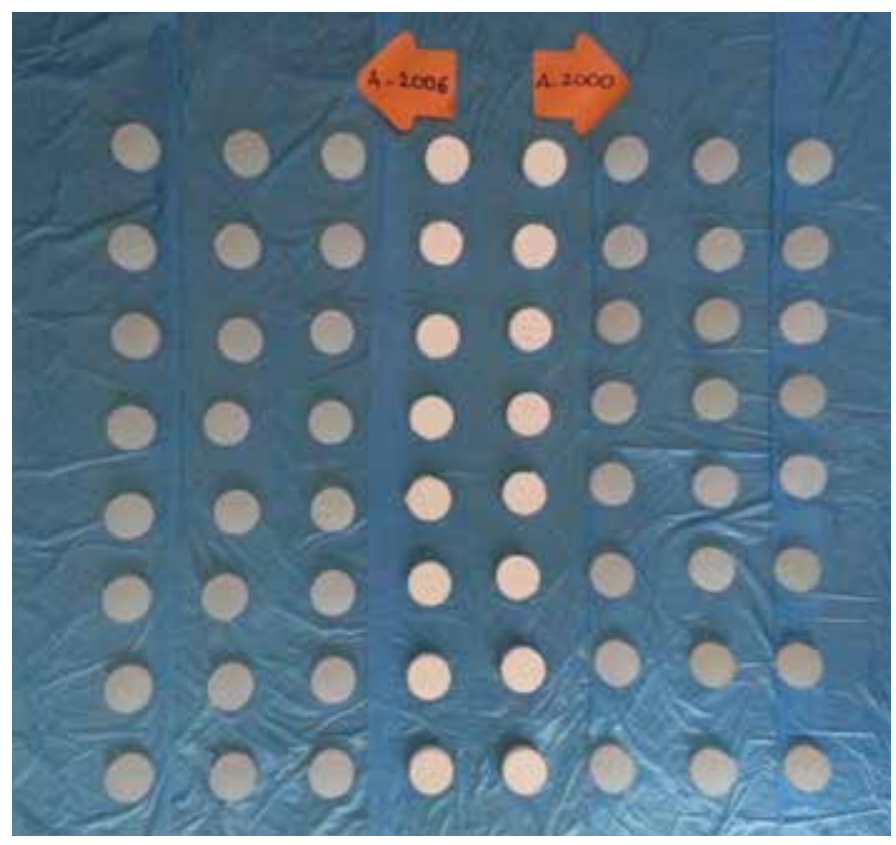

Figure 1. Silicone specimens after polymerization process. 


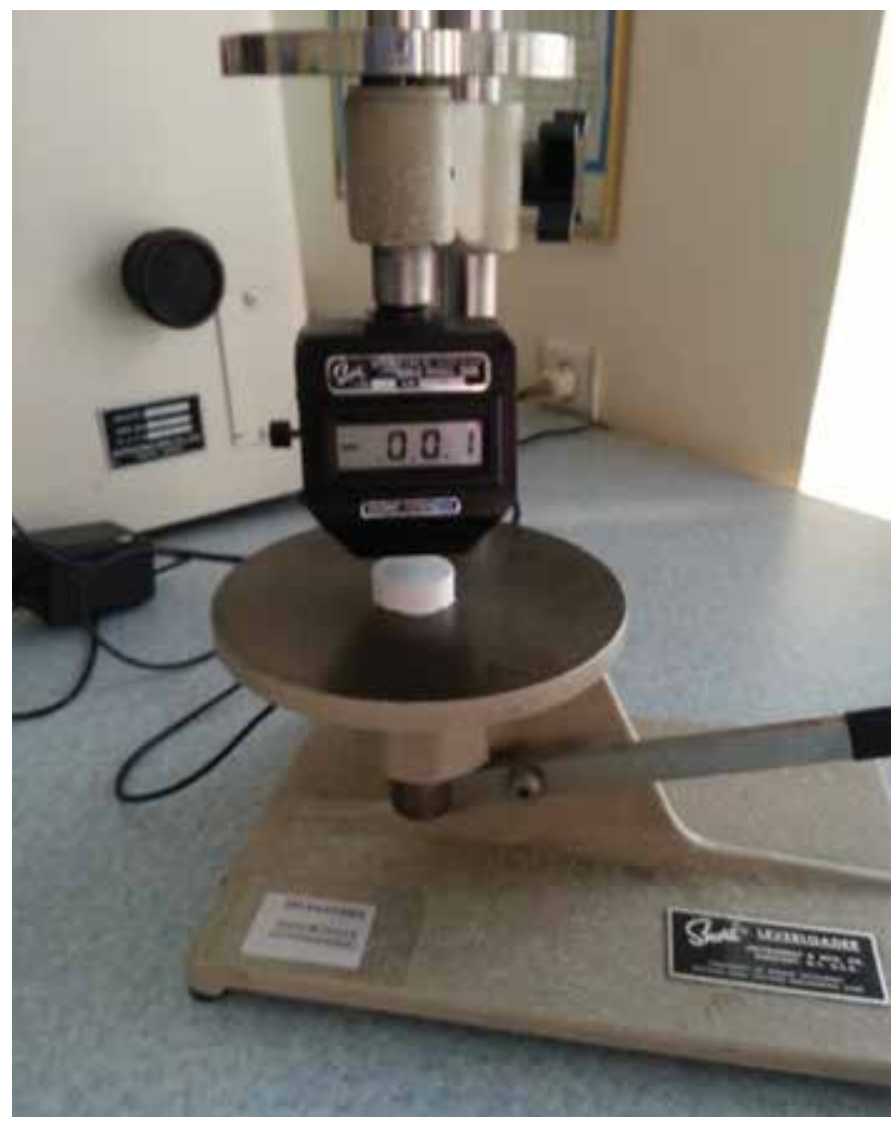

Figure 2. Shore A testing of the specimens.

A-2000

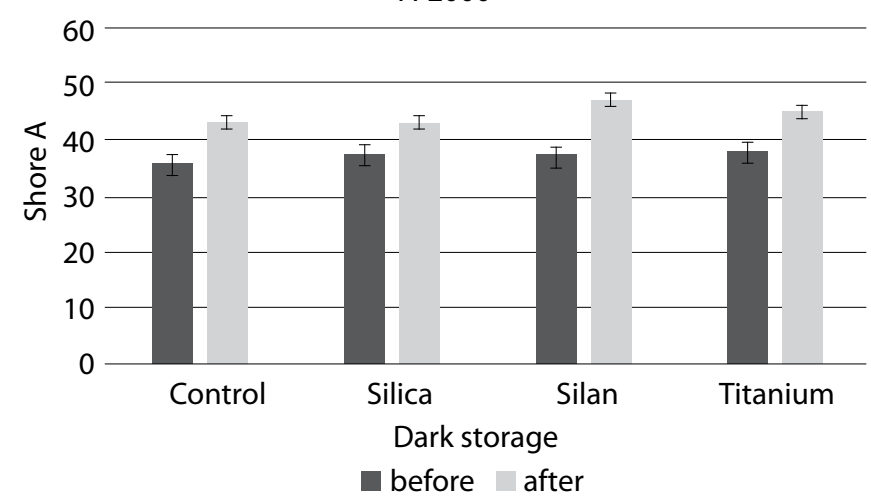

Figure 3. Paired t-test results, hardness (Shore A) values of A-2000 silicone before and after dark storage.

\section{A-2006}

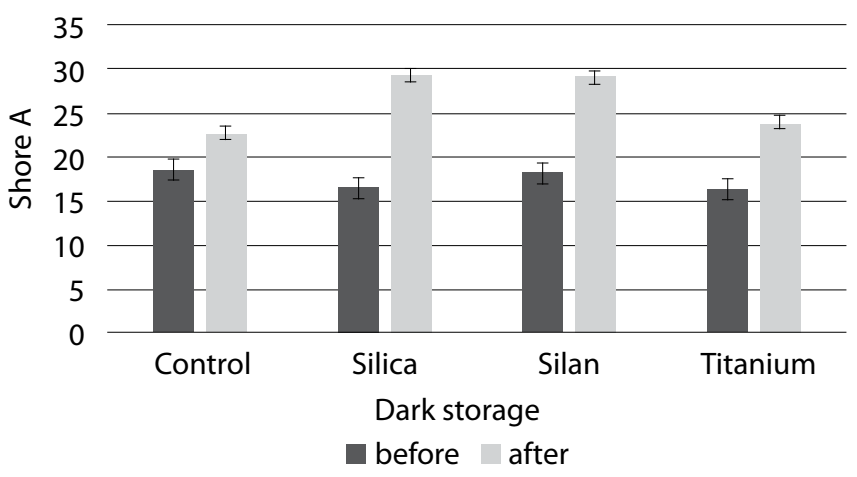

Figure 4. Paired t-test results, hardness (Shore A) values of A-2006 silicone before and after dark storage.
(SPSS IBM Corp.; Armonk, NY, USA). The standard descriptive methods such as the mean, standard deviation, minimum and maximum were applied to determine the characteristics of the sample. All data were first evaluated with Levene's test for homogeneity of variances and with Kolmogorov-Smirnov for normality. Paired t-test was used to evaluate the differences between the initial and the final hardness values of each nanoparticle groups in each silicone material. Because the data was normally distributed, one-way analysis of variance (ANOVA) with Tukey's Honestly Significant Difference (HSD) tests pairwise comparisons was used to compare the nanoparticle groups in each silicone group, respectively. Confidence interval was set to $95 \%$ and $p$ values less than 0.05 statistically significant.

\section{Results}

ANOVA results are presented as the mean and standard deviation in Table 2 and Table 3, and t-test results are presented in Figure 3 and Figure 4.

As can be seen from Table 2, ANOVA results revealed that statistically significant difference was found among groups after dark storage $(p<0.001)$. The lowest hardness value was observed in fumed silica group in A-2000 silicone elastomer. However, there was no significant difference between control and silica groups. While the highest hardness value was observed in $\mathrm{TiO}_{2}$, the significant difference was found between control and $\mathrm{TiO}_{2}$ groups $(\mathrm{p}=0.003)$. According to ANOVA results for the hardness values of A-2006 silicone (Table $3)$, there was statistically significant difference among the groups $(p<0.001)$. The lowest hardness value was observed in control group. Furthermore, while the highest hardness value was observed in silica group, there was not statistically significant difference between silica and silane groups in A-2006 silicone elastomer. According to paired t-test results, there was a significant difference between the hardness of each type of silicone and silicone subgroups before and the after storage $(p<0.001)$. Shore A hardness of all specimens significantly increased after dark storage.

\section{Discussion}

In this study, it was found that 2 years of dark storage adversely affected Shore A hardness of the silicone specimens. Furthermore, regarding after-storage specimens, nanoparticle incorporation did not reduce the hardness of the silicone elastomers as compared to control groups. The hardness values of silicone elastomers after 2-years dark storage varied from 47.28 to 22.75 , for A-2000 and A-2006, respectively. Both silicone elastomers, with or without nanoparticles, demonstrated significant hardness increase after dark storage. However, Shore A values of stored specimens were found to be consistent with the hardness values of silicone elastomers reported by Veres et al. $(1,11)$.

Many studies evaluated Shore A hardness of silicone elastomers for periods of $2(12), 6(13-15)$ or $12(16,17)$ months with measurements taken at the initial and the final observation periods. Because the standard clinical longevity of the 
Table 1. Information on the materials used in this study

\begin{tabular}{|c|c|c|}
\hline Material & Type & Manufacturer \\
\hline RTV Silicone & A-2000 & $\begin{array}{l}\text { (Factor II Inc. Lakeside; } \\
\text { AZ, USA) }\end{array}$ \\
\hline RTV Silicone & A-2006 & $\begin{array}{l}\text { (Factor II Inc. Lakeside; } \\
\text { AZ, USA) }\end{array}$ \\
\hline Fumed Silica & Cab-O-Sil & $\begin{array}{l}\text { (Factor II Inc. Lakeside; } \\
\text { AZ, USA) }\end{array}$ \\
\hline TiO2 & 30nanoTi & (Imicryl, Turkey) \\
\hline Silanated silica & S-812 & (Imicryl, Turkey) \\
\hline Thixotropic agent & A-300-1 Thixo & $\begin{array}{l}\text { (Factor II Inc. Lakeside; } \\
\text { AZ, USA) }\end{array}$ \\
\hline
\end{tabular}

RTV: room temperature vulcanized

Table 2. Final Shore A values for A-2000 silicone elastomer

\begin{tabular}{lccccc} 
Groups & N & Mean & SD & Min & Max \\
\hline Control & 8 & $43.32^{\mathrm{a}}$ & 1.0 & 41.23 & 44.43 \\
\hline Silica & 7 & $43.12^{\mathrm{a}}$ & 1.3 & 40.23 & 44.60 \\
\hline Silan & 8 & $47.28^{\mathrm{b}}$ & 1.0 & 45.26 & 48.86 \\
\hline Titanium & 8 & $45.39^{\mathrm{c}}$ & .7 & 44.20 & 46.44 \\
\hline Total & 31 & 44.70 & 1.9 & 40.23 & 48.86
\end{tabular}

Different superscript letters indicate the significant differences between groups Means with same lowercase letters are not significantly different SD: standard deviation

Table 3. Final Shore A values for A-2006 silicone elastomer

\begin{tabular}{lccccc} 
Groups & N & Mean & Std Dev & Min & Max \\
\hline Control & 8 & $22.75 \mathrm{a}$ & .7 & 21.42 & 23.72 \\
\hline Silica & 8 & $29.45 \mathrm{~b}$ & .6 & 28.53 & 30.16 \\
\hline Silan & 8 & $29.26 \mathrm{~b}$ & .5 & 28.38 & 30.06 \\
\hline Titanium & 7 & $23.91 \mathrm{c}$ & 1.0 & 22.50 & 25.22 \\
\hline Total & 31 & 26.24 & 3.1 & 21.42 & 30.16 \\
\hline
\end{tabular}

Different superscript letters indicate the significant differences between groups Means with same lowercase letters are not significantly different SD: standard deviation

facial prosthesis averages from 7 to 24 months $(6,18-22)$, it would be useful to evaluate the effect of time passage of at least 12-months on Shore A hardness of such silicone elastomers $(22,23)$. Therefore, the effect of long-term dark storage on the hardness value of silicone elastomers was evaluated in this study.

The relative hardness of a maxillofacial silicone elastomer should imitate the surrounding tissues and resemble the human skin (7). Facial prostheses during clinical service should be resistant and yet to soft and flexible to mimic the facial movements $(24,25)$. The acceptable limits of Shore $A$ values for a facial silicone elastomer range from 25 to 55 units (26).
The reason of different values considered to be acceptable clinically is due to the hardness variations that exist in the maxillofacial area.

It was reported that physical changes of maxillofacial elastomers that occur during natural aging could result from polymerization by-products, initiators (15), pigments and other fillers $(2,27)$. In this study, nanoparticle fillers adversely affected the hardness values of silicones after dark storage. However, hydrophilic fumed silica nanoparticles decreased the hardness value of A-2000 silicone as compared to control group. Hydroxyl groups of the hydrophilic fumed silica could generate hydrogen bonds between the silica and silicone. Thus, fumed silica could increase the mechanical properties of silicones (28). Most studies reported that fumed silica nanoparticles could increase the mechanical properties of silicone elastomers $(1,29,30)$.

Nano-oxide particles have been used as fillers in silicone elastomers to strengthen the mechanical properties of elastomers. By cross-linking reactions, nano-oxide particles could increase the surface energy of silicone matrix, which leads to a reinforced matrix structure $(31,32)$. In recent studies, titanium dioxide nanoparticles were found to increase the mechanical properties of silicone elastomers $(1,7,33)$. According to the results of this study, it could be stated that fumed silica nanoparticles might be effective on the mechanical properties of A-2000 silicone elastomer while $\mathrm{TiO}_{2}$ nanoparticles might be effective on the mechanical properties of A-2006 silicone elastomer.

Most studies on silicone elastomers subjected to dark storage are generally based on color stability $(2,23,25,34,35)$. However, limited research investigated the mechanical properties of silicone elastomers subjected to dark storage (17, $25,27,36)$. Furthermore, our study has a main difference with recent studies in which we investigated the effect of nanoparticle addition on the hardness of silicone elastomers after being subjected to dark storage.

Hardness increment during dark storage could result from continuous vulcanization $(12,36,37)$ of the silicone elastomers due to the presence of nanoparticles. A possible explanation of hardness increment could be a mechanism that may start due to oxygen intake during dark storage and generates cross-linkers which cluster in the silicone matrix, leading to denser network and higher hardness for silicone materials $(17,38)$.

The hardness of the silicone elastomers is controlled by the surface characteristics of the polymer network and the density of crosslink as reported by Polyzois et al. (17) Furthermore, the density of the cross-linkers could affect the length of the polymer chain (39) which results in degradation of mechanical properties of silicon elastomers in time. Therefore, another possible reason for increased hardness of nanoparticle added silicones could be that nanoparticles maximize the network of silicone matrix, lengthen of the polymer chain, leading to increased hardness values.

Lai and Hodges (40) and Raptis et al. (41) reported that the silicone elastomers are not completely vulcanized in stone molds. Furthermore, stone molds have more surface irregularities than the metal molds do (1). Accordingly, new generation silicone elastomers are polymerized in metal molds (40). 
Although stone molds can imitate the clinical fabrication techniques, metal molds were preferred for the polymerization process of the silicone elastomers to provide accurate and standard data in this study.

Various studies have used nano particles as fillers at different concentrations. Fillers used in this study were at $10 \%$ by volume, which is consistent with previous studies $(30,33)$ and it is based on the results of a recently published article (1), in which the mechanical properties of silicones were evaluated after nanoparticle incorporation. Thus, different concentrations of nano particles could lead to differences in mechanical and physical properties of silicone elastomers. Therefore, future research should address the effects of adding such nanoparticles at different concentrations on the mechanical and physical properties of maxillofacial silicone elastomers subjected to aging process.

\section{Conclusion}

Within the limitations of this in vitro study, it can be stated that the hardness of A-2000 and A-2006 silicone elastomers increased after 2-years dark storage. On the other hand, both silicone elastomers, with or without nanoparticles, showed clinically acceptable Shore A hardness values even after dark storage. Nanoparticle addition did not prevent silicone elastomers from hardening effects of time and, finally, A-2000 silicone revealed maximum hardness values in all study groups.

Ethics Committee Approval: Ethics committee approval was received for this study from the ethics committee of 12.01.2012 with the number 2012/01.

Informed Consent: There is no need for an informed consent form for the current in vitro study.

Peer-review: Externally peer-reviewed.

Author Contributions: PÇ designed the study, generated, gathered and analyzed the data, wrote and approved the final version of the paper.

Conflict of Interest: The author have no conflicts of interest to declare.

Financial Disclosure: The author declared that this study has received no financial support.

Türkçe öz: Maksillofasiyal silikonlarda Shore A sertlik ölçümü: karanlık ortam ve nanopartiküllerin etkisi. Amaç: Nanopartikül ilavesinin maksillofasiyal silikonların sertliğine olan etkisi hakkında yeterince çalısma bulunmamaktadır. Bu çalışmanın amacı, farklı nanopartikül ilavesi ve iki yıl karanlık ortam yaşlandırmasının maksillofasiyal silikon elastomerlerin sertliğine olan etkisini incelemektir. Gereç ve Yöntem: Çalışmada RTV tip A-2000 ve A-2006 silikon elastomerler test edilmiştir. Silanlanmış silika, tütsülenmiş silika ve titanyum dioksit nanopartikülleri hacimce $\% 10$ oranında doldurucu olarak kullanılmıștır. Her bir silikondan 30 x $10 \mathrm{~mm}$ boyutlarında sekiz örnek olmak üzere, kontrol grubu dahil toplam 64 silikon örnek hazırlanmıştır. Illk Shore A sertlik değerleri alınan örnekler oda sıcaklığında karanlık ortamda iki yıl boyunca saklanmış ve örneklerin yaşlandırma sonrasına ait ikinci Shore A değerleri kaydedilmiştir. Veriler istatistiksel olarak analiz edilmiştir. Bulgular: Her tip silikon için, gruplar arasında sertlik değerleri açııından istatistik- sel olarak anlamlı farklar gözlenmiştir $(p<, .001)$. Yaşlandırma sonrası; A-2000'e ait tütsülenmiş silika en düşük sertlik değerleri verirken, kontrol grubu ile arasında anlamlı bir fark bulunamamıştır. A-2006 için, kontrol grubu en düşük sertlik değeri verirken, en yüksek sertlik değeri tütsülenmiş silika grubunda gözlenmiştir. A-2006 'ya ait tütsülenmiş silika ve silanlanmış silika grupları arasında istatistiksel olarak anlamlı bir fark gözlenmemiştir. Sonuç: Yaşlandırma işlemi sonrasında maksillofasiyal silikonlara ait sertlik değerleri klinik olarak kabul edilebilir değerler arasında kalmıştır. Bununla birlikte, nanopartikül ilavesi silikon elastomerleri yaşlandırma işlemi sırasında ortaya çıkan sertlik artışına karşı koruyamamaktadır. Anahtar kelimeler: Yaşlandırma; sertlik; nanopartiküller; silkon elostomerler; Shore A

\section{References}

1. Cevik P, Eraslan O. Effects of the addition of titanium dioxide and silaned silica nanoparticles on the mechanical properties of maxillofacial silicones. J Prosthodont 2017; 26: 611-5. [CrossRef]

2. dos Santos DM, Goiato MC, Sinhoreti MA, Moreno A, Dekon SF, Haddad MF, Pesqueira AA. Influence of natural weathering on colour stability of materials used for facial prosthesis. J Med Eng Technol 2012; 36: 267-70. [CrossRef]

3. Akash RN, Guttal SS. Effect of incorporation of nano-oxides on color stability of maxillofacial silicone elastomer subjected to outdoor weathering. J Prosthodont 2015; 24: 569-75. [CrossRef]

4. Akay C, Cevik P, Karakis D, Sevim H. In vitro cytotoxicity of maxillofacial silicone elastomers: Effect of nano-particles. J Prosthodont 2018; 27: 584-7. [CrossRef]

5. Goiato MC, Pesqueira AA, Ramos da Silva C, Gennari Filho $H$, Micheline Dos Santos D. Patient satisfaction with maxillofacial prosthesis. Literature review. J Plast Reconstr Aesthet Surg 2009; 62: 175-80. [CrossRef]

6. Hatamleh MM, Haylock C, Watson J, Watts DC. Maxillofacial prosthetic rehabilitation in the uk: A survey of maxillofacial prosthetists' and technologists' attitudes and opinions. Int J Oral Maxillofac Surg 2010; 39: 1186-92. [CrossRef]

7. Han Y, Kiat-amnuay S, Powers JM, Zhao Y. Effect of nano-oxide concentration on the mechanical properties of a maxillofacial silicone elastomer. J Prosthet Dent 2008; 100: 465-73. [CrossRef]

8. O'Brein WJ. Dental materials and their selection. Michigan: Quintessence Publishing, 2002, p.23.

9. Polyzois GL, Tarantili PA, Frangou MJ, Andreopoulos AG. Physical properties of a silicone prosthetic elastomer stored in simulated skin secretions. J Prosthet Dent 2000; 83: 572-7. [CrossRef]

10. Dootz ER, Koran A, 3rd, Craig RG. Physical properties of three maxillofacial materials as a function of accelerated aging. J Prosthet Dent 1994; 71: 379-83. [CrossRef]

11. Veres EM, Wolfaardt JF, Becker PJ. An evaluation of the surface characteristics of a facial prosthetic elastomer. Part I: Review of the literature on the surface characteristics of dental materials with maxillofacial prosthetic application. J Prosthet Dent 1990; 63: 193-7. [CrossRef]

12. Polyzois GL. A study of the effect of crosslinking of hydroxyl terminated polydimethylsiloxane. Doctoral Dissertation, University of Wales, 1987.

13. Hatamleh MM, Polyzois GL, Silikas N, Watts DC. Effect of extraoral aging conditions on mechanical properties of maxillofacial silicone elastomer. J Prosthodont 2011; 20: 439-46. [CrossRef]

14. Haug SP, Andres CJ, Munoz CA, Okamura M. Effects of environmental factors on maxillofacial elastomers: Part III--physical properties. J Prosthet Dent 1992; 68: 644-51. [CrossRef]

15. Haug SP, Moore BK, Andres CJ. Color stability and colorant effect on maxillofacial elastomers. Part II: Weathering effect on physical properties. J Prosthet Dent 1999; 81: 423-30. [CrossRef] 
16. Wiens JP. A comparative study of selected elastomers subjected to accelerated and outdoor weathering. Doctoral Dissertation, University of Minnesota, 1980.

17. Polyzois GL, Eleni PN, Krokida MK. Effect of time passage on some physical properties of silicone maxillofacial elastomers. J Craniofac Surg 2011; 22: 1617-21. [CrossRef]

18. Chen MS, Udagama A, Drane JB. Evaluation of facial prostheses for head and neck cancer patients. J Prosthet Dent 1981; 46: 538-44. [CrossRef]

19. Hooper SM, Westcott T, Evans PL, Bocca AP, Jagger DC. Implant-supported facial prostheses provided by a maxillofacial unit in a U.K. Regional hospital: Longevity and patient opinions. J Prosthodont 2005; 14: 32-8. [CrossRef]

20. Jani RM, Schaaf NG. An evaluation of facial prostheses. J Prosthet Dent 1978; 39: 546-50. [CrossRef]

21. Jebreil K. Accetability of orbital prostheses. J Prosthet Dent 1980; 43: 82-5. [CrossRef]

22. Visser A, Raghoebar GM, van Oort RP, Vissink A. Fate of implant-retained craniofacial prostheses: Life span and aftercare. Int J Oral Maxillofac Implants 2008; 23: 89-98.

23. Hulterstrom AK, Ruyter IE. Changes in appearance of silicone elastomers for maxillofacial prostheses as a result of aging. Int J Prosthodont 1999; 12: 498-504.

24. Montgomery PC, Kiat-Amnuay S. Survey of currently used materials for fabrication of extraoral maxillofacial prostheses in North America, Europe, Asia, and Australia. J Prosthodont 2010; 19: 482-90. [CrossRef]

25. Polyzois G, Lyons K. Monitoring shore a hardness of silicone facial elastomers: The effect of natural aging and silicone type after 1 year. J Craniofac Surg 2014; 25: 1217-21. [CrossRef]

26. Conroy B, Haylock C, Hulterstrom AK, Pratt G, Winter RW. Report of a four year research and development programme involving the institute of maxillofacial technology and the university of wales institute of science and technology aimed at the production of a new facial prosthetic system. Proc Inst Maxillofac Technol 1979; 218-45.

27. Al-Harbi FA, Ayad NM, Saber MA, ArRejaie AS, Morgano SM. Mechanical behavior and color change of facial prosthetic elastomers after outdoor weathering in a hot and humid climate. J Prosthet Dent 2015; 113: 146-151. [CrossRef]

28. Aziz T, Waters M, Jagger R. Development of a new poly(dimethylsiloxane) maxillofacial prosthetic material. J Biomed Mater Res B Appl Biomater 2003; 65: 252-61. [CrossRef]
29. Andreopoulos AG, Evangelatou M, Tarantili PA. Properties of maxillofacial silicone elastomers reinforced with silica powder. J Biomater Appl 1998; 13: 66-73. [CrossRef]

30. Karayazgan-Saracoğlu B. Silika ile güçlendirilmiş maksillofasiyal silikon elastomerlerin fiziksel özelliklerinin değerlendirilmesi. Cumhuriyet Dent J 2010; 13: 34-9.

31. Frogley MD, Ravich D, Wagner HD. Mechanical properties of carbon nanoparticle-reinforced elastomers. Comp Sci Technol 2003; 63: 1647-54. [CrossRef]

32. Watson S, Beydoun D, Scott J. Preparation of nanosized crystalline $\mathrm{TiO} 2$ particles at low temperature for photocatalysis. J Nano Res 2004; 6: 193-207. [CrossRef]

33. Mirabedini SM, Mohseni M, PazokiFard SH, Esfandeh M. Effect of TiO2 on the mechanical and adhesion properties of rtv silicone elastomer coatings. Colloids Surf A Physicochem Eng Asp 2008; 317: 80-6. [CrossRef]

34. Bankoglu M, Oral I, Gul EB, Yilmaz H. Influence of pigments and pigmenting methods on color stability of different silicone maxillofacial elastomers after 1-year dark storage. J Craniofac Surg 2013; 24: 720-4. [CrossRef]

35. Takamata T, Moore BK, Chalian VA. Evaluation of color changes of silicone maxillofacial materials after exposure to sunlight. Dent Mater J 1989; 8: 260-70. [CrossRef]

36. Hatamleh MM, Watts DC. Effect of extraoral aging conditions on color stability of maxillofacial silicone elastomer. J Prosthodont 2010; 19: 536-43. [CrossRef]

37. Guiotti AM, Goiato MC, dos Santos DM. Evaluation of the shore a hardness of silicone for facial prosthesis as to the effect of storage period and chemical disinfection. J Craniofac Surg 2010; 21: 323-7. [CrossRef]

38. Pieter $G$, Jacques $S$. Oxygen uptake measurements to identify the cause of unexpected differences between accelerated and outdoor weathering. Angew Makromol Chem 1998; 261-262: 77-82. [CrossRef]

39. Mouzakis DE, Papadopoulos TD, Polyzois GL, Griniari PG. Dynamic mechanical properties of a maxillofacial silicone elastomer incorporating a $\mathrm{ZnO}$ additive: The effect of artificial aging. J Craniofac Surg 2010; 21: 1867-71. [CrossRef]

40. Lai JH, Hodges JS. Effects of processing parameters on physical properties of the silicone maxillofacial prosthetic materials. Dent Mater 1999; 15: 450-5. [CrossRef]

41. Raptis CN, Yu R, Knapp JG. Properties of silicone maxillofacial elastomer processed in stone and metal. J Prosthet Dent 1980; 44: 447-50. [CrossRef] 